\title{
Literary Translation and (or as?) Conflict between the Arab World and the West
}

\author{
Mustapha Ettobi \\ McGill University
}

\section{Introduction}

In 1990, Edward Said wrote an article entitled "Embargoed Literature" which was published in The Nation. In it, he argues that Arabic literature is "embargoed" in the West even if one of its most prominent figures, the Egyptian novelist and short story writer Naguib Mahfouz, was awarded the Nobel Prize for Literature in 1988. Said spoke of some "singular" reasons for this situation:

[...] of all the major world literatures, Arabic remains relatively unknown and unread in the West for reasons that are unique, and I think remarkable at a time when tastes here [the United States] for the non-Western are more developed than before and, even more compelling, contemporary Arabic literature is at a particularly interesting juncture (Said 372).

Although Said's article was well received by Arab and non Arab critics and researchers (such as Richard Jacquemond, 1992), its main argument was also challenged by other critics and scholars such as Peter Clark (2000). The latter maintained that Arabic literature in translation has significantly progressed since 1988 and has been more reviewed and studied than before. In this article, I do not intend to either defend or question Said's view but would like to examine an important issue which is central to his article: the impact of geopolitical conflicts on literary translation. I will be looking specifically at the influence of conflicts between the Arab world and the West on the translation of their respective literatures into Arabic or Western languages (mainly French and English). I will try to show that geopolitics can have an effect on literary translation and that interregional problems can encourage or impede its development, depending on the nature of the situation under study.

In the major studies that have so far been devoted to the translation of Arabic literature into Western languages and the rendering of Western literary works into Arabic, it has often been deemed necessary to mention or allude to the geopolitical relations between the Arab countries and the West (in particular France, Great Britain and the United States) because of past or present colonial 
relations. ${ }^{1}$ This fact has made me think and posit that translation between these worlds is in many ways influenced by, if not originating from, geopolitical conflicts (wars, colonization, etc.) involving them. I would like to develop this idea by shedding light on some specific historical phases extending from the $18^{\text {th }}$ century to the current post-9/11 era. My purpose is not to give an extensive account of the development of translation between these regions (or a history of their relations) nor a comprehensive list of the translations made, which would be impossible here. Rather, I will consider some periods that have been deemed by various critics as turning points in this translation history. In addition, these periods are more illustrative than others of the impact of geopolitical relations between the Arab world and the West on the translation exchange between them.

\section{Bonaparte's Expedition to Egypt}

In 1798, Napoleon Bonaparte sent a French expedition to Egypt. The latter was living at that time under Ottoman rule. The expedition was undertaken mainly as a move to "protect" French nationals in that country, to free the local population from "despotic" Mamelouk rulers (Brégeon 61-62) as well as to curb the strategic expansion of Great-Britain in the area. Although the French expedition lasted only three years, its effects on Egypt and the Arab world will extend far beyond the $18^{\text {th }}$ century.

In actual fact, the Egyptians failed to repel the French army. The latter did liberate the local population from "tyrannical" rulers. It laid bare the weakness of the Mamelouks, who were enfranchised slaves turned officials under the Ottoman rule. More importantly, it brought the Arabs a sharp awareness of the differences from the West, meaning Europe, in terms of military power and intellectual progress. This impelled the succeeding local rulers to seek knowledge from Europe in an attempt to bridge the gap. Thus in the $19^{\text {th }}$ century, Muhammad Ali, the governor of Egypt, sent a group of scholars to France to study and set up a school of translation. One of these scholarly missions was headed by Rifa'a Rafi' al-Tahtawi, a religious guide and a linguist, who supervised the first translations from French into Arabic of books dealing mainly

\footnotetext{
${ }^{1}$ Paul Starkey, for example, sees that "The history of literary translation from Arabic into English is divisible into distinct but overlapping phases, corresponding approximately with the evolution of the geo-political relationship of the English-speaking and Arabic-speaking worlds" (139).
} 
with historical, technical, military and scientific subjects. ${ }^{2}$ Clearly, Ali had a specific purpose: building a modern state (and country) with a strong military. ${ }^{3}$ As a result, literature was overlooked. Ironically, the first literary translation was undertaken not in Egypt but in the Sudan. Al-Tahtawi's fall from grace and his exile in the Sudan led to his arabization of Fénelon's Les Aventures de Télémaque. The selection of this work is probably due to al-Tahtawi's appreciation of the Western, namely French, political system and may have been intended as an indirect criticism of the ruler of Egypt. As a title for the translation, al-Tahtawi opted for Mawaqi' al-Aflak fi Waqai' al-Tilimak (meaning literally The Positions of the Celestial Bodies in the Adventures of Telemaque [Telemachus]). This overt adaptation of the title according to the literary and stylistic canon at that timenotice here the long title and the use of rhymes - foreshadows the main method used in that translation, namely the assimilation of the French text to Arab culture in general and its aesthetics in particular. This shows that the product of the French culture was not seen as having any kind of original superiority. This way of rendering French and other European texts into Arabic will remain the main tendency during the nineteenth century pending the rise of a new and modernist intellectual elite, which would be more familiar with mainstream literature in Europe and intent on modernizing Arabic literary writing.

Noteworthy here is the fact that the kind of works translated or rather assimilated into Arabic language and culture were often chosen for entertainment purposes since, from a religious point of view and given the practical purposes set for translation, they would be of no other use, a mere waste of time. The conservative cultural background against which literary translations were produced made no room for them except as non-mainstream literary books designed for personal ephemeral pleasure. Yet, this translation movement will soon flourish as printing was introduced and newspapers were

\footnotetext{
${ }^{2}$ According to Mona Baker, among the most important translations made are "various histories of the ancient world and the Middle Ages, histories of various kings and emperors, Montesquieu's Considérations sur les causes de la grandeur des Romains et leur décadence, as well as a large body of texts on medicine, geography, military sciences and other technical subjects" (323).

${ }^{3}$ In fact, as Jurgi Zaydan (1911) explains, Muhammad Ali sent many scholarly missions to Europe to learn sciences. He also founded various schools (a total of 16 in 1839), including four for military training, one for teaching European languages (like English and French) and others for teaching sciences such as medicine, architecture, industry, agriculture and administration. He was keen on building a modern state with a strong army. As far as his military ambitions are concerned, Zaydan informs us that Ali crashed the Mamelouks and the Wahhabites and made a few conquests in the Arab world, namely in the Sudan and Syria (18).
} 
established. Thus, more Egyptians and other Arabs (Lebanese, Syrians, etc.) gained gradual access to them. ${ }^{4}$ As a result, many books of this kind of light literature (adventures, love stories, fairy tales, etc.) were rendered into Arabic. It was only later that the first groups of Arab scholars and new intellectual elites, more familiar now with the current literary developments in Europe, started taking Western literature seriously and showing interest in canonical texts. Thus works by La Fontaine, Corneille, Victor Hugo, Lamartine, Musset, Vigny, Baudelaire, Shakespeare, Milton, Keats, Butler, Shelley and Kipling, for example, were translated at the end of the $19^{\text {th }}$ century (Tomiche 1 ). As time went on, translators began to render European texts in a more appropriate manner, gradually shunning assimilationist techniques (like changes in characters' names and story events and sometimes even the omission of the author's name), avoiding direct didactic or moral commentary, which had been made in order to meet the readers' expectations, and adopting a simpler, less 'ornamented', style.

\section{Post-Second-World-War Era}

On the other hand, Western nations, and mainly France and Great Britain, did not show any kind of sustained interest in Egypt and the Arab world's literary production from the time of Ali's rule until the 1940s. As Nada Tomiche states in her book, La Litterature arabe traduite, translations of Arabic works into English and French and other European languages began, in reality, only after the Second World War : "Vers la moitié du XX siècle [...], l'orientation du mouvement de traduction cesse d'être unilatérale, quand l'Occident commence à traduire, surtout en langues française et anglaise, les œuvres arabes modernes" [About half-way through the $20^{\text {th }}$ century, the orientation of the translation movement ceases to be unilateral when the West begins to translate modern Arabic works especially into French and English] (2; my translation). But even then the number of works was very limited, barely some 401 translations made into six languages (French, English, Italian, German, Spanish and Portuguese) between 1948 and 1968. Tales and the One Thousand and One Nights were the most selected works since some 275 translations thereof were produced, whereas only 74 contemporary literary texts and 52 other classics were made available in the same languages (Tomiche 2).

\footnotetext{
${ }^{4}$ I would not like to give the impression that the translation of Western literary works into Arabic in the $19^{\text {th }}$ century were undertaken only by Egyptians, but also by other Arabs, especially Syrians. It should also be mentioned that Syria at that time included present-day Lebanon.
} 
In the Arab world, Egypt remained the main cultural centre for translations of Western literary works. This is due, among other factors, to political reasons. In the aftermath of the 1952 revolution, known as the Revolution of the Free Officials, King Faruq lost grip on the power. Two years later, Gamal Abdel Nasser was proclaimed President of the Republic of Egypt. The new leader is known for his nationalistic ideals and ambitions. He was the first to nationalize the Suez Canal in 1956, triggering a tripartite attack on Egypt by France, GreatBritain and Israel in the same year. Yet, despite these facts, the Nasser "socialist" era continues to be considered as the one of the most prolific periods in terms of translations of Western literary works into Arabic. This was due mainly to what is known as the "1000 Book Project" (Machrou'a al-Alf Kitab) which aimed at promoting the project of acculturation for which the modernist elites of the "liberal age" strove (Jacquemond 148) and making foreign literatures, mainly Western ones, available to Egyptians and indirectly to other Arab readers. Thus, numerous translations of literary texts from English and French were undertaken and sponsored by the Egyptian state. Among the authors translated we find Sartre, Camus, Beckett, Ionesco, Brecht, Kafka and T. S. Eliot. Some classics were also rendered into Arabic like Cervantes' Don Quixote (1957-1958) and Dante's Comedia Divina (1959-1964) (Jacquemond 148).

In the West, however, interest in Arabic literature remained limited. Most probably, this was due to the power differentials in the relations between Arab and European countries. Most of the former were living under French or British colonial rule and striving to attain independence. We notice a growing interest in the West for Arabic literature only in the 1970s. The geopolitical situation changed: the decolonization phase was almost complete as Algeria became independent from France in 1962. Moreover, Arabic literature-namely poetry, short stories and the novel became more mature and interesting for foreign readers. $^{5}$

\footnotetext{
${ }^{5}$ After the Second World War and the gradual decolonization of the Arab world, Arabic literature underwent important changes because the local writers were able to focus on more personal issues rather than the mainly nationalist ones that were urgent in colonial times. The failure of the Arab states to meet the demands of their increasing populations and the defeats that they suffered at the hands of Israel, especially in 1967, led a deep questioning of nationalist ideals. There was an urgent need for social and political criticism. This gave birth to a variety of approaches and styles. Badawi calls this period "the Age of Conflicting Ideologies" (11). This does not mean that Arab writers ceased to tackle nationalist issues. Rather, they were expected to be engaged. Yet, this engagement was not limited to nationalist concerns. Rather, it permeated their own analysis of Arab society (the woman's situation for example) and culture (the issue of identity) in general. Thus, for the Western readers, their works would look less topical, political
} 
Prominent among the translators of this phase is Denys Johnson-Davies. Born in Vancouver in 1922 and educated mainly in England, this man has devoted a lot of his time to bringing Arabic literature to English-speaking readers. After sixty years of experience, he is credited with some 30 translations. Yet his merit derives not only from the number of texts he made available in English but also from the variety and quality of his work. In fact, he translated novels, short stories, plays, poetry, tales for children and other genres. Moreover, and despite being a disciple of a prominent Orientalist, Reynold A. Nicholson, his translation method is relatively opposed to the Orientalist translation method. ${ }^{6}$ The latter, construed in a scientific way, implies mainly rigid literalism, non assimilation and the inclusion of extensive notes. Although Johnson-Davies is a fervent advocate of pragmatic literalism, his awareness of the misconceptions and negative representations of Arab culture in general has, in my opinion, made of him a model for translators wishing to bring about a positive change in the exchange of literary works between the Arab world and the West. Not only does he question these preconceptions in his various prefaces to translations or in interviews but he also encourages English-speaking readers to learn about the Arab world and its culture. ${ }^{7}$

In 1988, as I said earlier, something happened that further stimulated the translation of Arabic literature into Western languages. Mahfouz, of whom Johnson-Davies translated a few works like Arabian Nights and Day and Echoes of an Autobiography, was awarded the Nobel Prize for literature. It could be argued that this event was the only major development apparently not connected with any conflict involving the Arab world and the West, which gave some

(anticolonial or anti-West), and 'propagandistic'.

${ }^{6}$ Johnson-Davies, for example, takes to task some Orientalists for overemphasizing the alterity of the target culture by trying to explain all the foreign aspects of the source texts and failing to respect their aesthetic properties. For him, such translation will only lead to the production of other "treatises" on "the Manners and Customs of Modern Egyptians" (Ghazoul et al. 85), a telling allusion made to William Lane's Orientalist work on life in Egypt. It is an implicit criticism of the scholarly translation of Arabic texts, which ends up giving detailed accounts of the source culture and forfeiting the literary aspects of the translated work. It should be noted here that Lane produced an English translation of Alf Layla wa Layla (or the One Thousand and One Nights). He conceived of it as "an extension of his earlier work of depicting and explaining the manners and customs of the modern Egyptians, which [he] considered to be more or less unchanged since the Middle Ages" (Irwin 24).

${ }^{7}$ For a detailed discussion of Johnson-Davies' translations, his criticism of Orientalist methods and his contribution to the translation of Arabic literature into English, see Ettobi (2006). 
momentum to the translation of Arabic literary works into Western languages. Yet, even in this case, the shadow of conflict looms, though less heavily. It has been argued that among the reasons for which Mahfouz was given the most prestigious literary prize are his political views. ${ }^{8}$ In fact, he voiced some support for the Camp David peace agreement brokered by the former president of the United States of America, Jimmy Carter, and signed by Egypt and Israel in 1978, that is, in the wake of the Nasser era. For this reason, he was allegedly chosen among a list of Arab authors presented to the Academy. Yet, despite this argument against the merit of this writer, his literary talent is unquestionable and his prolific production is unequaled by any of the other candidates, including the Sudanese writer Tayeb Salih. Mahfouz wrote some forty literary works and had it not been for an attack by two Egyptian extremists against him in Cairo and the serious injuries he suffered at their hands, he would have written more. By bringing up this issue here, I intend to show that the translation movements between the Arab world and the West are not immune from the conflicts that can exist not only between but also within them. ${ }^{9}$ Noteworthy here is that Mahfouz's literary works have been translated, especially after 1988, into many Western and other languages. These translations could easily number in the hundreds.

Yet, in spite of all the progress made, many critics (like Jacquemond and Abboushi-Dallal) still consider the translation of Arabic literature into Western languages an inadequate activity. All have felt a lack of real interest in it or a tendency to translate literary works that confirm "stereotypical" images of the Arab world. Johnson-Davies himself sees that a Nobel Prize has not considerably changed the publishers' and editors' treatment of this literature (Ghazoul et al. 1983). The same thing is more or less maintained by Said for whom it is as though:

\footnotetext{
${ }^{8}$ Brad Kessler wrote that "The Nobel panelists found a safe bet: a humanist who called for peace with Israel and would be palatable to the Western press" (60)

${ }^{9}$ A case in point is the retranslation of Mahfouz's novel Awlad Haratina, which appeared in 1994. It was produced by Peter Theroux and entitled Children of the Alley. The first one, Children of Gebelawi, had been made by John Stewart in 1981. Mahfouz's "controversial" novel, partially a rewriting of the stories of Judaism, Christianity and Islam, had been unofficially censored in Egypt in the 50s when it was serialized in a local newspaper. The new attention paid to this text in 1994 was probably due to the debate sparked by Salman Rushdie's novel The Satanic Verses, which angered radical Islamists, as well as to the attempt on Mahfouz's life.
} 
an iron curtain of indifference and prejudice ruled out any attention to texts that did not reiterate the usual clichés about 'Islam,' violence, sensuality, and so forth. A seemingly deliberate policy maintains a kind of monolithic reductionism where the Arabs and Islam are concerned; the Orientalism that distances and dehumanizes another culture is upheld, elevating and strengthening at the same time the xenophobic fantasy of a pure 'Western' identity (374).

Richard Jacquemond shares much of Said's opinions, including his criticism of Orientalism. He also sees that:

The translation of Arabic literature remains determined by the global relationship between Orient, especially the Arabic Orient, and Occident. The latter's perceptions are biased by prejudices constructed through a long and complex mutual history. The Occidental reader prefers to turn to works which confirm his prejudices and his representation of the Orient (154-155).

In a book published in 2000 entitled Arabic Literature Unveiled: Problems of Translation, Clark touched on the same problem but in a different way. Although the general purpose of his book is to show the "remarkable" progress of the translation of Arabic literature into English after 1988, some of his concluding remarks reveal, among other things, the existence of conflicting views or perceptions, namely the bias in the Arab world against the West:

The modern Arab world has often been sensitive to outside interest in its affairs. 'Orientalism' is by definition bad. [...] American and European interest is, therefore, subject to suspicion. Arabs have not been alone in apprehension of outsiders' curiosity. Plenty of parallels can be found from the Chinese to the Welsh. But there is sometimes combined with this hostility to Orientalism a complaint that there is an in-built 'Western' hostility to Arab interest and culture [...]. A readiness to bomb particular Arab regimes, such as those of Iraq or Libya, is seen to support it. (23)

Yet, for Clark, this "bias" is rather reciprocal. He sees that:

There is, alas, no doubt that some people are anti-Arab. Hostility towards and prejudice against individuals, national or racial groups is a fact of life and nourishes most political, strategic and military confrontations. A reading of the British popular press shows that there is nothing unique in anti-Arabism. Globalisation has not vanquished xenophobia.

While this quotation proves, in Clark's opinion, that the existence of conflictual views of the Other in both the Arab world and the West, England in this case, hinders the translation, and reception, of their literary works, it downplays any bias against Arab culture, reducing it mostly to social problems 
between specific groups within a given community, be it England, the United States or France. It tends to suggest that the whole Arab world suspects the West's interest in it whereas only "some people" in the West are suspicious of Arabs. It does not take into consideration the colonial past and its long-term effects on the relations between the two regions. It falls short of recognizing the major problem of cultural dialogue (or the lack of it?) between them, of which translation is an important aspect. This is very true now that the 9/11 attacks, the London and Madrid bombings and the ongoing wars in Iraq and Afghanistan, as an Islamic country, have to some extent enlarged the cultural distance between them and seemed to have proven the fears and suspicions of the two sides to be "true" and made the future of the translation of Arabic literature into Western languages look less promising as several translation projects, like "Mémoires de la Méditerranée", have come to an end, because of lack of funds, or remain in the limbo.

\section{Conclusion}

In the initial title I proposed for this article, I ask the question whether translation is a conflict between the Arab world and the West. The examples I have given show that it is not the case. They show that conflicts can lead to translation, retranslation for specific social or political reasons, or even a translation movement with unpredictable developments. Translation is rather influenced by conflicts involving it. This influence, which, in general, does not abide by any laws of predictability, depends on the internal social, political, cultural and economic circumstances in which it happens and is accordingly shaped.

It is my hope that literary translation between Arabic and Western languages will be devoted to promoting a better knowledge of the Other's culture in general. This aim could be achieved by further promoting translation between these two entities as well as by diversifying the literary works chosen for this purpose. Adopting such strategies will allow for a more nuanced understanding of the Other's worldview and the evolution and heterogeneity of his/her culture. Thus, translation will be a means of resolving conflicts - by creating culture-conscious public opinions and promoting culture-friendly decision-making - if not diminishing the probability of their occurrence in the future. This is why I believe that scholarly debate on the theme of conflict and translation, which may look confrontational to some, should be encouraged if a 
TranscUlturAl, vol.1, 1(2008), 14-24

http://ejournals.library.ualberta.ca/index.php/TC

true and a solid basis for cultural dialogue between the West and the Arab world, and between other cultures, is indeed wanted. 
http://ejournals.library.ualberta.ca/index.php/TC

\section{Works Cited}

Badawi, M. M.. A Short History of Modern Arabic Literature. Oxford: Clarendon Press, 1993.

Baker, Mona. "Arabic Tradition." The Encyclopedia of Translation Studies. London: Routledge (1997) 317-325.

Brégeon, Jean-Joël. L'Egypte française au jour le jour: 1798-1801. Paris: Perrin, 1991. Clark, Peter. Arabic Literature Unveiled: Challenges of Translation. Durham: University

of Durham, Centre for Middle Eastern and Islamic Studies: 2000.

Ettobi, Mustapha. “Denys Johnson-Davies: figure de la traduction de la littérature arabe."

TTR_19.1 (2006) 73-95.

Ghazoul, Ferial et al. “On Translating Arabic literature.” An Interview with Denys

Johnson-Davies. Alif 3 (1983) 80-93.

Irwin, Robert. The Arabian Nights: A Companion. London: Penguin Press, 1994. Jacquemond, Richard. Entre scribes et écrivains: Le champ littéraire dans l'Égypte contemporaine. Paris: Actes Sud/Sinbad, "La bibliothèque arabe," 2003.

- - - " "Translation and Cultural Hegemony: The Case of French-Arabic Translation." Rethinking Translation: Discourse, Subjectivity, Ideology. Ed. Lawrence Venuti. London/New York: Routledge (1992) 139-158.

Kessler, Brad. "Laureate in the Land of the Pharaohs." New York Times Magazine. June 3, 1990. 39, 60-62, 68-70, 80.

Said, Edward. "Embargoed Literature." The Politics of Dispossession. New York: Pantheon Books (1990; 1994) 372-378.

Starkey, Paul. "Modern [Arabic] Literature." The Oxford Guide to Literature in English Translation. Ed. Peter France. New York: Oxford UP (2000) 152-156.

Tomiche, Nada. La Littérature arabe traduite. Paris: Geuthner, 1978.

Zaydan, Jurgi. Tarikh Adab al-Lughah al-'Arabyah. Vol. 4. Al-Fajjalla (Egypt): Matba'at al-Hilal, 1914. 